\title{
Congenital cystic adenomatoid malformation - diagnostic and therapeutic procedure: 8-year experience of one medical centre
}

\author{
Bogumiła Strumiłło ${ }^{1}$, Andrzej Jóźwiak¹, Anna Pałka¹, Krzysztof Szaflik², Anna Piaseczna-Piotrowska1 \\ ${ }^{1}$ Department of Surgery, Urology and Children Transplantology, Institute of Mother's Polish Health Centre, Lodz, Poland \\ ${ }^{2}$ Department of Gynaecology, Reproduction and Fetal, Institute of Mother's Polish Health Centre, Lodz, Poland
}

Kardiochirurgia i Torakochirurgia Polska 2018; 15 (1): 10-17

\begin{abstract}
Introduction: Congenital cystic adenomatoid malformation (CCAM) is a rare anomaly. The mechanisms and the time at which the abnormality develops are still unclear. The malformation is characterized by the presence of single large or multiple but smaller cysts.

Aim: To present the experience of our medical centre, the Polish Mother's Memorial Hospital - Research Institute.

Material and methods: We analysed the medical records of 32 neonates hospitalized in 2008-2017 at the Department of Paediatric Surgery and Urology ICZMP due to pre- or postnatally diagnosed congenital cystic adenomatoid malformation. Results: In 2008-2017 32 children were hospitalized at our department due to prenatally diagnosed CCAM. An intrauterine procedure of thoracoamniotic shunting was performed in 13 fetuses. All newborns had chest computed tomography. Surgery had been performed in 21 children. Histopathological analysis of specimens prepared from the resected lung tissue confirmed type 1 CCAM in 4 cases, type 2 CCAM in 11 cases and type 3 CCAM in 1 case. Four patients were diagnosed with a bronchogenic cyst and one with extralobar pulmonary sequestration.

Conclusions: Postnatal management of CCAM depends on the clinical status of the newborn. Newborns without clinical symptoms require radiological diagnostics to confirm the presence of malformation. Surgical treatment is recommended before the age of 10 months. Resection of the malformed lung fragment in patients with CCAM is the first-line treatment. It should be emphasized that despite the tremendous advances in diagnostic imaging, the final diagnosis of CCAM is made based on histopathological findings.
\end{abstract}

Key words: congenital cystic adenomatoid malformation, thoracoamniotic shunting.

\section{Streszczenie}

Wstęp: Wrodzona malformacja gruczołowo-torbielowata płuc (CCAM) jest rzadką anomalią. Obecnie nieznane są zarówno mechanizmy, jak i czas powstania wady. Malformacja charakteryzuje się obecnością pojedynczych, dużych lub bardzo licznych, ale mniejszych torbieli, zwykle obejmujących pojedynczy płat płuca.

Cel: Przedstawienie doświadczenia naszego ośrodka - Instytutu Centrum Zdrowia Matki Polki (ICZMP) w Łodzi.

Materiał i metody: Przeprowadzono analizę dokumentacji medycznej noworodków hospitalizowanych w latach 2008-2017 w Klinice Chirurgii i Urologii Dziecięcej ICZMP w Łodzi z powodu pre- lub postnatalnie rozpoznanej CCAM.

Wyniki: W latach 2008-2017 w klinice hospitalizowano 32 dzieci z powodu prenatalnie rozpoznanej torbielowatości płuc. U 13 płodów wykonano zabieg wewnątrzmaciczny polegający na założeniu shuntu opłucnowo-owodniowego. U wszystkich noworodków wykonano badanie tomografii komputerowej klatki piersiowej. W chwili powstawania pracy zabieg chirurgiczny przeprowadzono u 21 dzieci. Wyniki badań histopatologicznych preparatów wyciętej tkanki płucnej potwierdziły obecność CCAM typu I w 4 przypadkach, typu II w 11 przypadkach, typu III w 1 przypadku. U 4 pacjentów wynik w badaniu histopatologicznym wykazał obecność torbieli bronchogennej, a u 1 - sekwestru zewnątrzpłucnego.

Wnioski: Postępowanie postnatalne zależy od stanu klinicznego noworodka. Noworodki bez objawów klinicznych wymagają diagnostyki radiologicznej w celu potwierdzenia obecności wady. Przeprowadzenie zabiegu rekomendowane jest w 10. miesiącu życia. Wycięcie fragmentu zmienionego płuca w przebiegu CCAM jest postępowaniem z wyboru. Należy podkreślić, że pomimo ogromnego postępu w diagnostyce obrazowej ostateczne rozpoznanie CCAM ustala się na podstawie badania histopatologicznego.

Słowa kluczowe: wrodzona malformacja gruczołowo-torbielowata płuc, shunt opłucnowo-owodniowy.

Address for correspondence: Bogumiła Strumiłło MD, Department of Surgery, Urology and Children Transplantology, Institute of Mother's Polish Health Centre, 281/289 Rzgowska St, 93-338 Lodz, Poland, phone: +48 502142 843, e-mail: bogumila.rosa@wp.pl

Received: 5.09.2017, accepted: 11.10.2017. 


\section{Introduction}

Congenital cystic adenomatoid malformation (CCAM) is a rare anomaly with reported incidence ranging from 1 in 25,000 to 1 in 35,000 live births [1]. It is usually an isolated disorder, although its coexistence with other lung defects, e.g. pulmonary sequestration, and cardiac or renal defects, has been reported [2]. The mechanisms and the time at which the abnormality develops are still unclear. Most likely, this defect is a result of arrested lung development in the early phase of fetal life (6-15 gestational weeks (GW)), which results in hypertrophy of bronchia/bronchioles and mesenchymal tissue and failure to develop alveoli [3]. Malformation is characterized by the presence of single large or multiple but smaller cysts usually involving a single lobe of lung. Multilobar lesions involving both lungs are very rare. A tendency for spontaneous resolution of the microcystic types of CCAM (usually after $28 \mathrm{GW}$ ) has been reported [4]. However, the postnatal regression of lesions is unlikely. The macrocystic type of CCAM does not tend to regress, and large fluid-filled cysts may compress the healthy lung parenchyma, causing its hypoplasia or mediastinal shift and compression of the lower vena cava, contributing to fetal cardiovascular insufficiency and to the development of generalised fetal hydrops [5]. Hydrops is associated with the risk of fetal death. If there is a risk of such complications, antenatal therapy should be considered [5].

In the postnatal period the key clinical symptoms of CCAM in the newborn depend on the type and severity of lung lesions. Pathological cysts filled with air that are in contact with normally developed bronchia and bronchioles can rapidly compress the remaining lung parenchyma,
Table I. Stocker histopathological classification of CCAM (2002)

\begin{tabular}{|l|l} 
Type 0 & $\begin{array}{l}\text { Development arrested at the stage of trachea/bronchia } \\
\text { formation; tracheal epithelium. Cysts smaller than } \\
0.5 \mathrm{~cm} \text {; tracheal epithelium, presence of cartilage }\end{array}$ \\
\hline Type 1 & $\begin{array}{l}\text { Development arrested at the stage of bronchia } \\
\text { formation; bronchial epithelium. Large } 4-10 \mathrm{~cm} \text { cysts, } \\
\text { cartilage rarely present, squamous-like epithelium }\end{array}$ \\
\hline Type 2 & $\begin{array}{l}\text { Development of the bronchial tree arrested at the } \\
\text { glandular stage. Multiple cysts }<2.5 \mathrm{~cm} \text {, covered with } \\
\text { columnar epithelium }\end{array}$ \\
\hline Type 3 & $\begin{array}{l}\text { Development of the bronchial tree arrested at the } \\
\text { glandular stage, typical adenomatoid malformation. } \\
\text { Multiple cysts }<1.5 \mathrm{~cm} \text {, covered with columnar epithelium }\end{array}$ \\
\hline Type 4 & $\begin{array}{l}\text { Development arrested at the stage of bronchia } \\
\text { formation; acinar epithelium. Cysts size } 2-4 \mathrm{~cm} \\
\text { (pleuropulmonary blastoma - PPB), cartilage absent }\end{array}$ \\
\hline
\end{tabular}

cause mediastinal shift, provoke disorders of venous circulation (venous flow), and lead to respiratory/cardiovascular insufficiency. After the neonatal period abnormal lung tissue may become a reservoir of secretions accumulated in cystic spaces and a source of recurrent infections [2]. Cases of malignant transformation in the abnormal lung tissue have also been reported [6].

In 1977 an American pathomorphologist, JT Stocker, described 3 histopathological types of CCAM. In 2002 he added another two types to the list ( 0 and 4 ), and his classification system is used to this day [7] (Table I). The most common types of CCAM are macrocystic type 1 (60\%) and microcystic type 2 (15-30\%) [7] (Figs. 1-3). Treatment for CCAM involves the resection of malformed lung tissue.

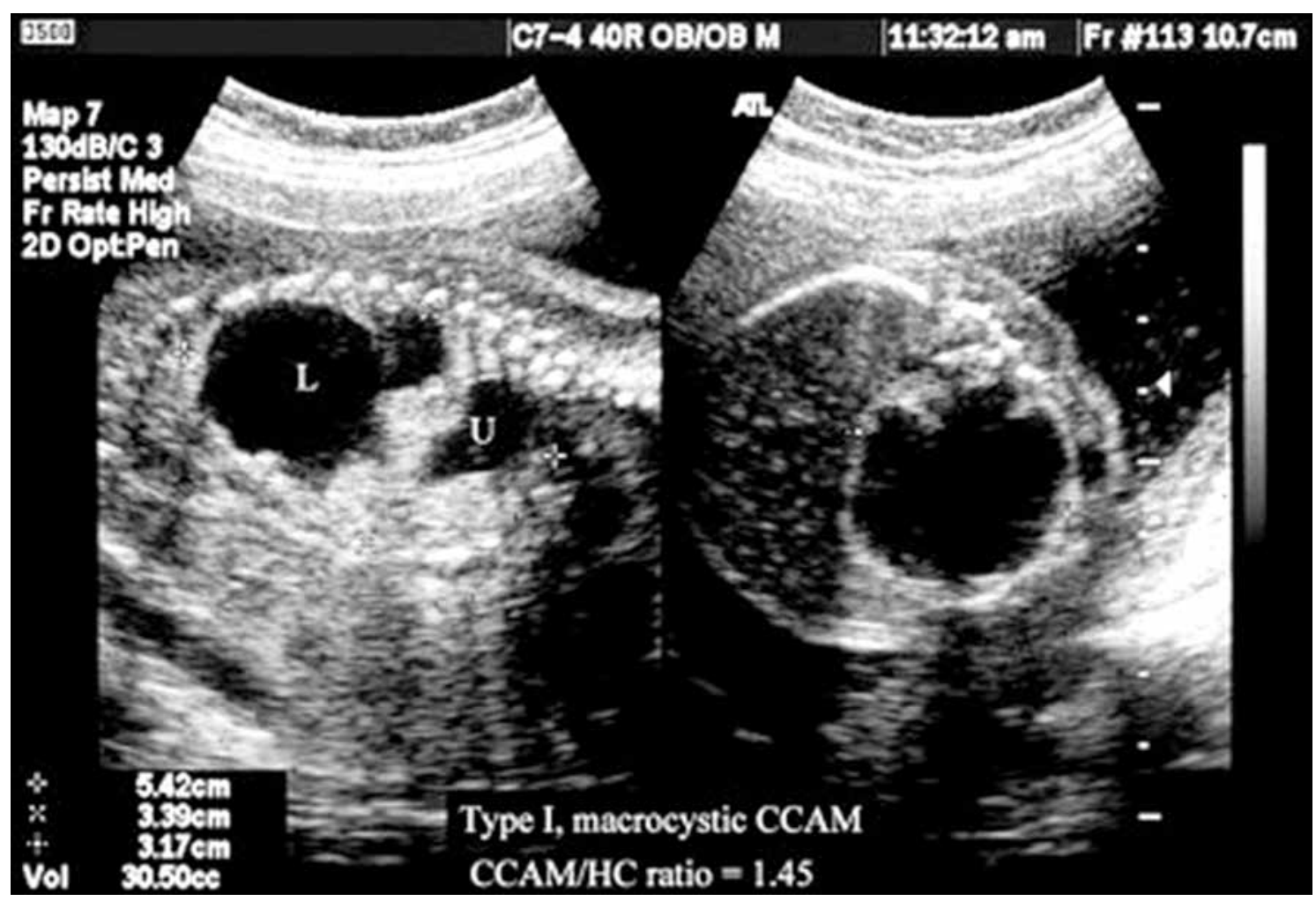

Fig. 1. Macrocystic CCAM (USG scan) 


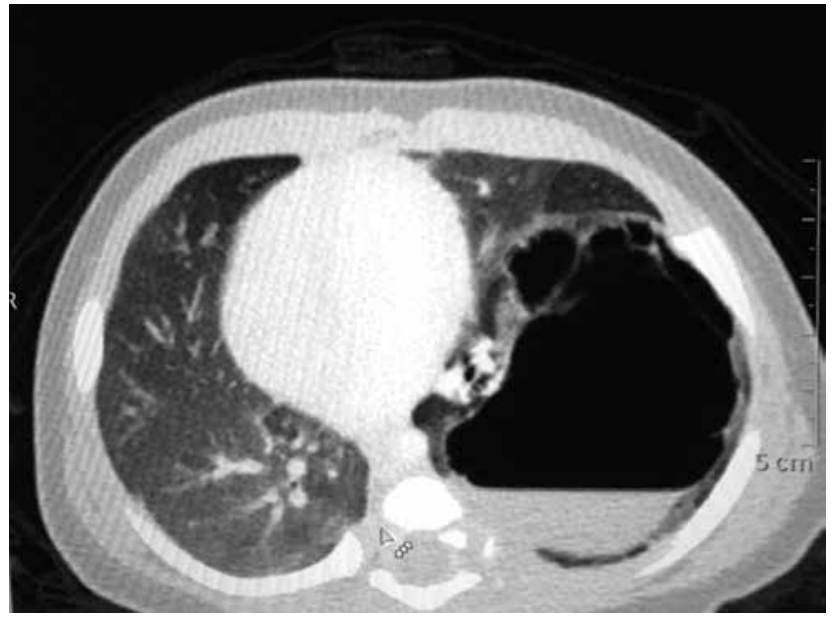

Fig. 2. Macrocystic CCAM (CT scan)
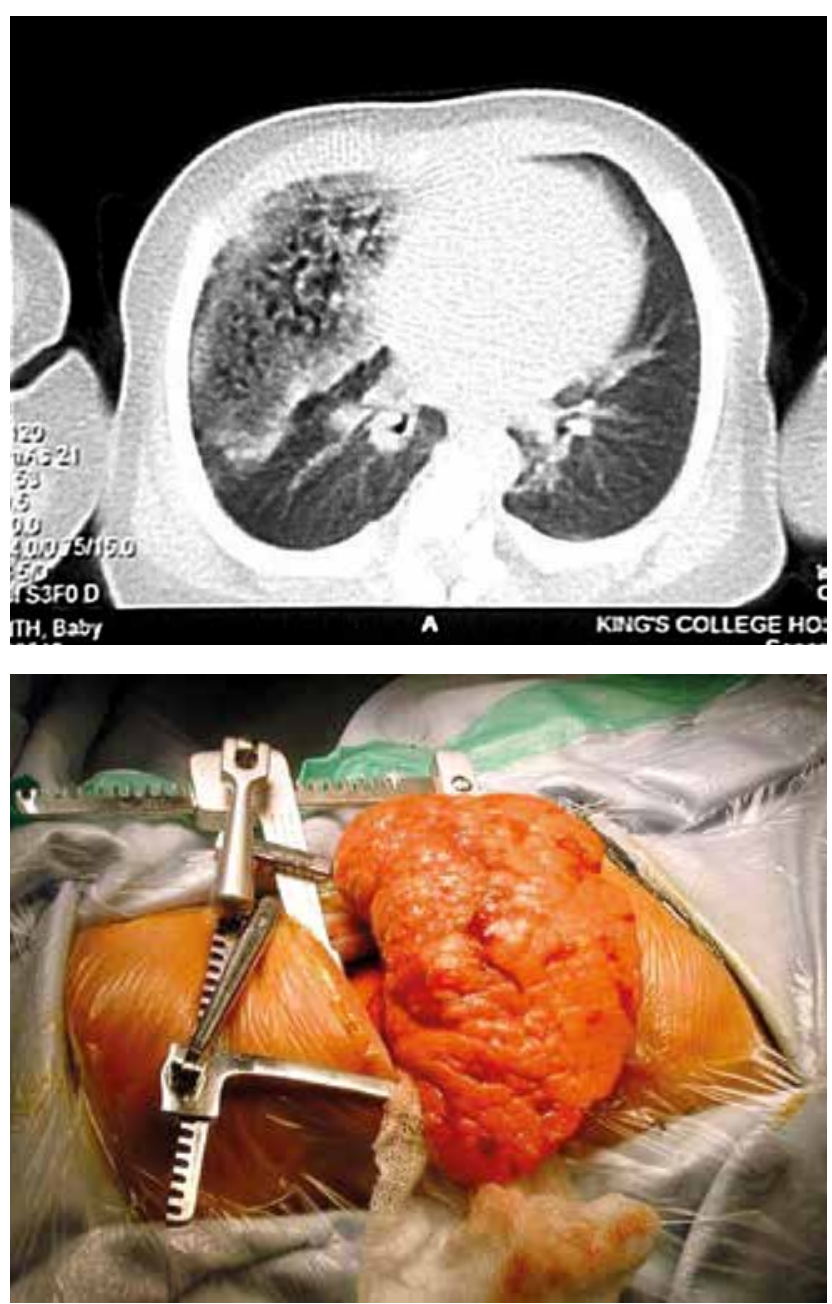

Fig. 3. Microcystic CCAM (CT scan and intraoperative imaging)

\section{Aim}

The aim of this study is to present the experience of our medical centre, the Polish Mother's Memorial Hospital - Research Institute in Lodz (ICZMP), in the preand postnatal diagnosis and treatment of newborns and infants with CCAM.

\section{Material and methods}

We analysed the medical records of neonates hospitalized in 2008-2017 at the Department of Paediatric Surgery and Urology ICZMP in Lodz due to pre- or postnatally diagnosed congenital cystic adenomatoid malformation. The collected data concerned:

- The prenatal period, including the gestational age at the time of diagnosis of malformation, the type of malformation based on fetal ultrasonography, and indications, type and duration of prenatal intervention.

- The postnatal period: gestational age, body weight, Apgar score at birth, sex of the child, clinical assessment in the first days of life, type and location of the malformation in the computed tomography (CT) scan, presence of accompanying defects, age of the patient at the time of surgery, findings from histopathological examination of the resected fragment of the lung, and existing accompanying defects. Type of malformation was assessed using the Stocker classification system (2002) covering five types of CCAM (0-4).

\section{Results}

In 2008-2017, 32 children (17 girls, 53\%; 15 boys, 47\%) were hospitalized at the Department of Paediatric Surgery and Urology ICZMP in Lodz due to prenatally diagnosed congenital cystic adenomatoid malformation. Malformation was diagnosed and monitored using ultrasound scan (US) (Fig. 1 - fetal US). Gestational age of the fetuses at diagnosis was in the range of 20-33 GW (mean $26 \mathrm{GW}$ ). Echocardiography was also performed in 23 (72\%) fetuses. Examination revealed heart defects in 4 children: cardiomyopathy $(n=1)$, ventricular septal defect $(n=2)$, and aortic stenosis with dextrocardia $(n=1)$. An intrauterine procedure of thoracoamniotic shunting was performed in 13 fetuses. The procedure was indicated due to an expanding cystic lesion that compressed the residual lung parenchyma and caused mediastinal shift. In addition mothers were diagnosed with progressing polyhydramnios.

At birth the gestational age of the paediatric patients ranged between 30 and $40 \mathrm{GW}$ (mean $38 \mathrm{GW}$ ). Most children from the study group were born full-term $(n=26)$. In 6 cases, there was an indication for the early termination of pregnancy. This group included 3 newborns who in the prenatal period underwent the procedure of thoracoamniotic shunt placement. Indications for the early termination of pregnancy included threatening fetal asphyxia $(n=1)$, cardiovascular disease of the mother $(n=1)$, orthopaedic problems of the mother $(n=1)$, and spontaneous onset of preterm labour $(n=3)$. Caesarean section was performed in 20 cases and 12 children were delivered vaginally.

The general health of most newborns from the study group $(n=25)$ after delivery was good (Apgar score 9-10 points). This group included 9 newborns who had a prenatal procedure of thoracoamniotic shunt placement. Six newborns, including 2 treated prenatally, received moderate scores due to respiratory effort and suspected congenital infection (Apgar 7-8 points). Serious or very serious 
health problems with severe respiratory insufficiency and the need for intubation were diagnosed in one neonate (Apgar 1-6) born with asphyxia at 30 weeks of gestation. In this newborn, an intrauterine procedure was performed, complicated by bleeding into the pleural cavity.

All newborns had chest CT, usually on day 7 after birth (Fig. 2). Depending on the cyst size newborns were diagnosed with macrocystic CCAM $(n=13)$ or microcystic CCAM $(n=11)$. In other children $(n=8)$ CT scan revealed solid cystic lesions.

Postnatal diagnostic procedures also showed the presence of coexisting defects in $8(25 \%)$ children with CCAM, including heart defects $(n=4)$, cleft palate $(n=1)$, CNS cysts $(n=1)$, urinary tract defects - PCS dilatation $(n=1)$, and one child was diagnosed with haemophilia. Of the above, only heart defects were diagnosed prenatally.

By the time of manuscript preparation, surgery had been performed in 21 children. In 6 newborns the procedure was carried out between 8 and 20 days of life due to progressing respiratory insufficiency. Other patients $(n=15)$ were qualified for elective surgery between 2 and 12 months of life. Non-operated patients $(n=11)$ are under the care of other medical centres and/or await surgical treatment. In 16 patients the procedure was performed by thoracotomy and in 5 by thoracoscopy. In 1 case the operator had to proceed from thoracoscopy to thoracotomy. During the surgery lobectomy was performed in 14 children and segmentectomy in 6 children. In 1 patient extrapulmonary sequestration was detected during thoracoscopy and the malformation was completely resected. Postoperative pleural drainage was maintained in all patients for 1 to 5 days (mean: 3 days). All children received perioperative and postoperative antibiotic therapy for 5 days on average (range: 3-7 days). The postoperative period was uneventful in $17(81 \%)$ children. During the post-operative period one child suffered a cardiac arrest with leakage of lymphatic fluid into the chest cavity. Despite preventive antibiotic therapy postoperative deterioration of respiratory function due to systemic infection was observed in 3 children. One of these children was preoperatively diagnosed with pulmonary infection. No deaths in the study group were reported.

Histopathological analysis of specimens prepared from the resected lung tissue confirmed type 1 CCAM in 4 cases, type 2 CCAM in 11 cases and type 3 CCAM in 1 case. Based on histopathological examination 4 patients were diagnosed with a bronchogenic cyst and 1 with extralobar pulmonary sequestration (Table II).

\section{Discussion}

With advances in fetal ultrasonography and recently introduced fetal magnetic resonance imaging, most congenital lung defects can be diagnosed in the early intrauterine period. It should be emphasized that lesions detected in the fetal ultrasonographic image of lungs are not specific just for CCAM. Increased echogenicity of the lung and the presence of cysts are described in other disorders, e.g. pulmonary sequestration, bronchogenic or enterogenous cysts, and in congenital lobar overinflation [8]. Therefore, a more generalized term such as congenital lung malformation (CLM) is used increasingly often. Imaging studies, including ultrasonography, $\mathrm{CT}$, and magnetic resonance (MR), are used to distinguish macrocystic, microcystic or a mixed, solid cystic type of malformation [9].

According to reports, fetal lung defects are usually diagnosed between 18 and $34 \mathrm{GW}$ [8]. In our study group CCAM was diagnosed on average at $26 \mathrm{GW}$. The evolution of the malformation is monitored in subsequent weeks of pregnancy, not only for prognostic purposes, but also for proper planning of fetal therapy. In the study group, a prenatal intervention involving shunt placement between the lumen of the lung cyst and amniotic fluid was performed in 13 fetuses. Indications for surgery included expansively growing cyst compressing the residual lung parenchyma, mediastinal shift in the fetus, and progressive hydramnios in the mother. Echocardiography was performed before surgery in all fetuses to confirm their cardiac status. This protocol is consistent with the latest recommendations [10]. Reports from leading medical centres offering fetal therapy in different countries have indicated that about $14 \%$ of fetuses with CCAM require prenatal intervention, most commonly thoracoamniotic shunting, which significantly improves the survival of fetuses with CCAM, and/or the possibility of steroid therapy [10]. For several years, attempts have also been made to perform radical intrauterine operations - removing pathological lung tissue in CCAM fetuses, particularly those at risk of developing or with existing generalized hydrops [10]. There are many questions as to the possibility of spontaneous regression of lung lesions in the prenatal period. Recent studies show that microcystic lesions previously described as lesions tending to resolution are often secondary to bronchial obstruction and fluid accumulation, rather than actual CCAM lesions [6].

Data on age and body weight of newborns at birth in the study group were consistent with those reported by other authors [11]. The gestational age of paediatric patients ranged between 30 and $40 \mathrm{GW}$ (mean $38 \mathrm{GW}$ ), and the mean birth weight was $3450 \mathrm{~g}$ (2730-3800 g). In $6 \mathrm{ca}-$ ses there were indications for the early termination of pregnancy due to threatening fetal asphyxia or the medical condition of the mother. This group included 3 newborns who received fetal therapy (Table III). Although some reports show that a fetal lung defect is not an indication for Caesarean section [12], most children $(n=20)$ from the study group were born in this way.

In neonates, the presence and severity of respiratory distress syndrome due to the extent and severity of lung lesions is crucial [13]. The rapid enlargement of pathological cystic spaces as a result of their aeration, compression of the normally developed lung parenchyma, and mediastinal shift are the most important factors worsening the general health status and increasing the severity of symptoms of respiratory insufficiency in newborns with CCAM. Pulmonary hypoplasia and the development of pulmonary hypertension or the coexisting defects may further aggravate the patient's condition [10]. According to some reports, 
Table II. Data of radiological and histopathological diagnosis

\begin{tabular}{|c|c|c|c|c|c|c|}
\hline Ordinal & $\begin{array}{l}\text { Type of CCAM } \\
\text { in prenatal USG }\end{array}$ & $\begin{array}{l}\text { Localisation } \\
\text { in USG }\end{array}$ & $\begin{array}{l}\text { Type of CCAM } \\
\text { in CT }\end{array}$ & Localisation in CT & $\begin{array}{c}\text { Time } \\
\text { of operation }\end{array}$ & Histopathology \\
\hline 1 & Macrocystic & Left lung & Macrocystic & Left lung, lower lobe & 20 days & ॥ \\
\hline 2 & Microcystic & $\begin{array}{l}\text { Left lung, } \\
\text { upper lobe }\end{array}$ & Microcystic & Left lung, upper lobe & 5 months & II \\
\hline 3 & CCAM/ sequestration & Left lung & Microcystic & Right lobe, segment 10 & Lack of contact & Lack of contact \\
\hline 4 & No result & No result & Macrocystic & Left lung, lower lobe & $\begin{array}{l}\text { Under the care } \\
\text { of another } \\
\text { department }\end{array}$ & - \\
\hline 5 & Microcystic & $\begin{array}{l}\text { Right lung, } \\
\text { middle lobe }\end{array}$ & Microcystic & Right lung, segment 10 & 8 days & II \\
\hline 6 & No result & No result & Microcystic & Left lung, upper lobe & 13 days & II \\
\hline 7 & No result & No result & Microcystic & Right lung, upper lobe & 4 months & II \\
\hline 8 & Microcystic & Left lung & Microcystic & $\begin{array}{l}\text { Left lung, segment } \\
9 \text { and } 10\end{array}$ & 10 months & II \\
\hline 9 & No result & No result & Macrocystic & $\begin{array}{c}\text { Right lung, segment } \\
8,9,10\end{array}$ & 2 months & Bronchogenic cyst \\
\hline 10 & Macrocystic & Right lung & Solid cystic lesions & Right lung & 2 months & II \\
\hline 11 & No result & No result & Microcystic & Left lung, segment 6 & Lack of contact & Lack of contact \\
\hline 12 & Macrocystic & $\begin{array}{l}\text { Left lung, } \\
\text { upper lobe }\end{array}$ & Macrocystic & $\begin{array}{l}\text { Left lung, segment } \\
1 \text { and } 2\end{array}$ & $\begin{array}{l}\text { Under the care } \\
\text { of another } \\
\text { department }\end{array}$ & $\begin{array}{l}\text { Under the care } \\
\text { of another } \\
\text { department }\end{array}$ \\
\hline 13 & Macrocystic & Right lung & Solid cystic lesions & $\begin{array}{l}\text { Right lung, segment } \\
4 \text { and } 5\end{array}$ & Lack of contact & Lack of contact \\
\hline 14 & Microcystic & Right lung & Macrocystic & $\begin{array}{l}\text { Right lung, upper } \\
\text { and middle lobe }\end{array}$ & 2 months & I \\
\hline 15 & Microcystic & Left lung & Macrocystic & Left lung, upper lobe & 4 months & 1 \\
\hline 16 & Macrocystic & Right lung & Macrocystic & $\begin{array}{l}\text { Right lung, segment } \\
6 \text { and } 10\end{array}$ & $\begin{array}{l}\text { Under the care } \\
\text { of another } \\
\text { department }\end{array}$ & $\begin{array}{l}\text { Under the care } \\
\text { of another } \\
\text { department }\end{array}$ \\
\hline 17 & No result & No result & Microcystic & $\begin{array}{l}\text { Right lung, segment } \\
6,9 \text { and } 10\end{array}$ & 4 months & $\|$ \\
\hline 18 & No result & No result & Solid cystic lesions & $\begin{array}{l}\text { Left lung, segment } \\
1 / 2 \text { i } 3\end{array}$ & No result & $\begin{array}{c}\text { Passed to another } \\
\text { department due to } \\
\text { haemophilia }\end{array}$ \\
\hline 19 & No result & No result & Macrocystic & Right lung, segment 2 & 7 months & Bronchogenic cyst \\
\hline 20 & No result & No result & Solid cystic lesions & $\begin{array}{l}\text { Right lung, segment } \\
9 \text { and } 10\end{array}$ & 4 months & $\begin{array}{c}\text { Pulmonary } \\
\text { sequestration }\end{array}$ \\
\hline 21 & Macrocystic & $\begin{array}{l}\text { Left lung, } \\
\text { middle part }\end{array}$ & Macrocystic & Left lung, lower lobe & Further diagnostics & Waiting \\
\hline 22 & Macrocystic & $\begin{array}{l}\text { Left lung, } \\
\text { upper lobe }\end{array}$ & Macrocystic & Left lung, lower lobe & 8 days & 1 \\
\hline 23 & No result & No result & Macrocystic & $\begin{array}{l}\text { Right lung, segment } \\
2 \text { and } 6\end{array}$ & 3 months & II \\
\hline 24 & No result & No result & Microcystic & $\begin{array}{l}\text { Right lung, segment } \\
6,8,9 \text { and } 10\end{array}$ & $\begin{array}{l}\text { Under the care } \\
\text { of another } \\
\text { department }\end{array}$ & $\begin{array}{l}\text { Under the care } \\
\text { of another } \\
\text { department }\end{array}$ \\
\hline 25 & Microcystic & Right lung & Macrocystic & $\begin{array}{l}\text { Right lung, upper } \\
\text { and lower lobe }\end{array}$ & 16 days & 1 \\
\hline 26 & No result & No result & Solid cystic lesions & $\begin{array}{l}\text { Left lung, segment } \\
9 \text { and } 10\end{array}$ & 4 months & Bronchogenic cyst \\
\hline 27 & Microcystic & Right lung & Microcystic & $\begin{array}{c}\text { Right lung, segment } \\
6,9,10\end{array}$ & 5 months & III \\
\hline 28 & No result & No result & Solid cystic lesions & Left lung, upper lobe & 10 months & Bronchogenic cyst \\
\hline 29 & No result & No result & Solid cystic lesions & Right lung, lower lobe & 12 months & II \\
\hline 30 & Microcystic & Left lung & Solid cystic lesions & Left lung, segment 1, 2, 3 & 10 days & II \\
\hline 31 & Sequestration & Right lung & Microcystic & Right lung, segment 10 & Classified & Classified \\
\hline 32 & Microcystic & Left lung & Macrocystic & Left lung, segment 10 & Classified & Classified \\
\hline
\end{tabular}


Table III. Data of prenatal care

\begin{tabular}{|c|c|c|c|c|c|c|c|c|}
\hline Ordinal & Gender & $\begin{array}{l}\text { Gestational age } \\
\text { at diagnosis }\end{array}$ & $\begin{array}{l}\text { Intrauterine } \\
\text { procedure }\end{array}$ & $\begin{array}{l}\text { Gestational age } \\
\text { of procedure }\end{array}$ & $\begin{array}{l}\text { Coexisting } \\
\text { defects }\end{array}$ & $\begin{array}{l}\text { Gestational } \\
\text { age }\end{array}$ & $\begin{array}{l}\text { Indication for the } \\
\text { early termination }\end{array}$ & $\begin{array}{c}\text { Apgar (1/5 } \\
\text { minute) }\end{array}$ \\
\hline 1 & $\mathrm{~F}$ & 29 & - & - & - & 39 & - & 9 \\
\hline 2 & M & 23 & - & - & $\mathrm{CoA}$ & 37 & $\begin{array}{l}\text { Spontaneous onset } \\
\text { of preterm labour }\end{array}$ & $8 / 8$ \\
\hline 3 & $\mathrm{~F}$ & 26 & - & - & - & 40 & - & $9 / 9$ \\
\hline 4 & $\mathrm{~F}$ & 26 & - & - & Heart hypertrophy & 38 & - & $9 / 9$ \\
\hline 5 & $\mathrm{~F}$ & 24 & Yes & 24 & - & 35 & $\begin{array}{c}\text { Orthopaedic } \\
\text { problems of the } \\
\text { mother }\end{array}$ & $7 / 7$ \\
\hline 6 & $\mathrm{~F}$ & 23 & Yes & 23 & - & 38 & - & 9 \\
\hline 7 & M & - & - & - & - & 39 & - & $9 / 9$ \\
\hline 8 & $\mathrm{~F}$ & 21 & - & - & - & 39 & - & 9 \\
\hline 9 & $\mathrm{~F}$ & - & - & - & - & 40 & - & 8 \\
\hline 10 & $\mathrm{~F}$ & 32 & Yes & 32 & - & 39 & - & $8 / 8$ \\
\hline 11 & $\mathrm{~F}$ & 25 & - & - & - & 37 & $\begin{array}{l}\text { Cardiovascular } \\
\text { disease of the } \\
\text { mother }\end{array}$ & $9 / 9$ \\
\hline 12 & M & 28 & Yes & 28,37 & - & 40 & - & $9 / 10$ \\
\hline 13 & $\mathrm{~F}$ & 20 & Yes & 22 & Cleft palate & 40 & - & 10 \\
\hline 14 & M & 31 & Yes & 31 and 32 & Brain cyst & 40 & - & 9 \\
\hline 15 & $\mathrm{~F}$ & 33 & Yes & 33 & - & 38 & - & 9 \\
\hline 16 & M & 23 & Yes & 23 & - & 38 & - & $8 / 9$ \\
\hline 17 & $M$ & b.d. & - & - & - & 39 & - & $8 / 9$ \\
\hline 18 & M & 25 & - & - & Haemophilia & 37 & $\begin{array}{l}\text { Spontaneous onset } \\
\text { of preterm labour }\end{array}$ & $8 / 8$ \\
\hline 19 & $\mathrm{~F}$ & 28 & - & - & - & 39 & - & $10 / 10$ \\
\hline 20 & M & 21 & - & - & VSD & 39 & - & $8 / 8$ \\
\hline 21 & M & 22 & Yes & 26,27 & - & 30 & $\begin{array}{c}\text { Threatening fetal } \\
\text { asphyxia }\end{array}$ & $1 / 1$ \\
\hline 22 & $M$ & 29 & Yes & 32 & - & 38 & - & 9 \\
\hline 23 & $\mathrm{~F}$ & 29 & - & - & - & 38 & - & 10 \\
\hline 24 & $\mathrm{~F}$ & 21 & - & - & - & 40 & - & 9 \\
\hline 25 & M & 25 & Yes & 25 & - & 37 & $\begin{array}{l}\text { Spontaneous onset } \\
\text { of preterm labour }\end{array}$ & 9 \\
\hline 26 & $M$ & b.d. & - & - & - & 38 & - & 9 \\
\hline 27 & $\mathrm{~F}$ & 33 & Yes & 33 & $\begin{array}{l}\text { Widening of the } \\
\text { pelvic system }\end{array}$ & 38 & - & 9 \\
\hline 28 & $M$ & 28 & - & - & - & 38 & - & 9 \\
\hline 29 & $M$ & 29 & - & - & - & 39 & - & 10 \\
\hline 30 & $\mathrm{~F}$ & 28 & Yes & 32 & VSD & 40 & - & $9 / 9$ \\
\hline 31 & $M$ & 25 & - & - & - & 40 & - & $9 / 9$ \\
\hline 32 & $\mathrm{~F}$ & 24 & - & - & - & 40 & - & $9 / 9$ \\
\hline
\end{tabular}

approximately $10-25 \%$ of newborns with congenital cystic lung lesions require surgical intervention in the early days of life [11]. Most cases of CCAM in the neonatal and earlyinfant period are asymptomatic [13]. The general health of most newborns in the study group $(n=25)$ after delivery was good (Apgar score 9-10 points). The health of 6 newborns was scored as moderate (Apgar 7-8 points) due to respiratory effort and suspected congenital infection. Seri- ous or very serious health problems (Apgar 1-6) with severe respiratory insufficiency and the need for intubation were diagnosed in one newborn who was treated in utero. At present, most authors indicate that bilateral lung lesions and the development of non-immune hydrops are very poor prognostic features and are associated with high mortality, especially in fetuses that received no prenatal intervention [14]. The extent and type of lung lesions, mediastinal shift 
and hydramnios may be considered negative prognostic factors, although many of the affected fetuses do not have clinical symptoms of malformation [15]. In the study group 13 newborns who underwent intrauterine therapy required surgery in the first 3 weeks of life due to progressing symptoms of respiratory insufficiency. Other newborns with asymptomatic malformation in the neonatal period received elective surgical treatment.

Due to the evolution of the image of lung lesions observed especially in the last weeks of pregnancy, postnatal computed tomography of the lung is recommended in all newborns with this anomaly [15]. Chest X-ray, especially if done in the first few days of life and in patients with small, limited lung lesions, may not visualise them. Magnetic resonance is a more useful test for the prenatal diagnosis of lung defects [16]. The time of CT examination mainly depends on the clinical status of the newborn. In neonates with clinical symptoms such as respiratory disorders, CT is performed in the first days of life, and in asymptomatic patients usually in the first month of life. In our study group all newborns had chest $C T$, usually on days $6-7$ of life. This study confirmed the prenatal diagnosis of cystic lung lesions in all examined neonates, and the CT image in most cases $(n=19)$ was consistent with the ultrasound image acquired prenatally. Based on CT imaging macrocystic CCAM was confirmed in 13 children and microcystic CCAM in 11 children. In other patients $(n=8)$ the CT scan revealed solid cystic lesions. Reports by other authors and the experience of our medical centre show that in some cases certain lung lesions are difficult to differentiate, even if CT is employed. This especially concerns the segmental areas that may suggest small airway obstruction, lobular emphysema, or CCAM [2]. In many cases resected lung fragments in histopathological examination turned out to be lesions associated with emphysema or bronchogenic cysts. Hybrid lesions are reported increasingly more often (about 25\% cases), and they contain features of adenoid cystic lesions and pulmonary sequestration, or segmental bronchial obstruction with or without emphysema and CCAM [17].

Lung lesions in CCAM usually affect a single lobe, usually the lower one and more often the left lung. Bilateral pathology is very rare [18]. In the study group lung lesions were usually located in the right lung $(n=17)$, mainly in segments $6,9,10$ of the lower lobe $(n=10)$, and less frequently in the upper lobe. In 15 children lesions were detected in the left lung, usually in the lower segments of the lower lobe. In the study group we did not observe prenatal or postnatal regression of pulmonary lesions, although cases of prenatal resolution are reported in the literature [19].

Children diagnosed with CCAM often have additional anomalies. In our study group most of these were heart defects, usually correlated with the solid type 2 CCAM. The coexistence of various defects suggests the same pathomechanisms underlying their abnormal embryogenesis [20].

Recent advances in thoracic surgery and anaesthesia have minimized the mortality of newborns and infants with congenital cystic pulmonary lesions. Today it is clear that pathological lung tissue has to be removed, and the only controversy is about the time of the procedure and its scope. In neonates with clinical symptoms the surgery should be performed after previous diagnostic imaging and stabilization of vital parameters [15]. In the study group 6 children were operated on in the early days of life due to progressing symptoms of respiratory insufficiency. Surgery was performed between 8 and 20 days of life. Other children $(n=15)$ were operated on between 1 and 12 months of life (mean: 5 and 6 months). Two children who did not show clinical symptoms of malformation during the monitoring before surgery were treated for lung infection. These children were operated on at the age of 2 or 4 months after the resolution of the lung infection. In the early postoperative period one of these patients developed respiratory insufficiency. A meta-analysis carried out in 2009 by Stanton et al. revealed that the age of 10 months and younger is the optimal time for the surgical treatment of children with asymptomatic cystic malformation of the lung [21]. During this time most patients begin to show the first clinical symptoms of the malformation, most often in the form of pulmonary infections. Many surgeons recommend an elective procedure at the age of 6 months or earlier, before the onset of pulmonary complications [15]. Many studies suggest that patients with CCAM-related clinical symptoms, especially pulmonary infections, have a significantly higher incidence of surgical and postoperative complications compared to patients with asymptomatic defects [22]. There are also reports indicating that the early resection of abnormal lung tissue allows for better development of the unaffected lung [22]. Only a small proportion of children with a minor segmental lesion may be monitored for a longer time [16]. If the treatment is postponed, the parents of the patient should be informed and made aware of the adverse consequences of the disease, primarily the increased risk of pulmonary infection or malignant transformation.

Many surgeons believe that in cases where pulmonary lesions are limited to a single lobe, the most appropriate surgical procedure is to remove the lesion completely (finding a clear border between CCAM and normal lung parenchyma may be difficult in macroscopic examination) and reduce the risk of early pleural effusion often observed after segmentectomy [23]. Thoracoscopic minimally invasive techniques are applied increasingly more often, both for lobectomy and segmentectomy, and are especially recommended in children with asymptomatic CCAM. The extent of pulmonary lesions and, above all, respiratory disorders in neonates are factors limiting the possibility of performing thoracoscopic procedures. A history of pulmonary infections significantly increases the risk of intraoperative conversion to classic thoracotomy and the possibility of postoperative complications including pneumothorax, bronchial fistula and septicaemia [24]. Children who have undergone segmentectomy $(n=4)$ in our centre are under constant ambulatory care, and control CT studies have not revealed pathological lesions in the surgically treated lung. 
No deaths were reported in the study group. According to different authors, a significant improvement in the mortality rate has been seen over the past few years in comparison with previous studies [12]. The deaths of children with CCAM are usually linked to postoperative complications. The size of lesions is considered an important prognostic factor for survival [16].

According to the literature, type 1 CCAM is most commonly diagnosed in the histopathological examination [17]. In our study, however, Stocker's type 2 CCAM (2002) was diagnosed most frequently. Baird et al. point to the fact that the image of cystic lung lesions in pre- and postnatal studies often does not correspond to the lesions found later in histopathological studies. Some reports suggest that the discrepancy rate for diagnostic findings is up to $17 \%$ [8]. This may be due to the unclear border between macroscopic and microscopic images, as well as the lack of a clear border in the histopathological image of particular CCAM types. Hybrid lesions that contain features of CCAM with sequestration are being reported with increasing frequency [17]. Diagnostic imaging studies often detect lesions in various respiratory phases of the lung and varying degrees of pathological cyst filling [25]. In the group of surgically treated children an initial diagnosis of CCAM made based on imaging studies (CT) was confirmed in most cases $(n=16)$ after histopathological examination. In four cases, histopathological examination revealed the presence of intrapulmonary bronchogenic cyst, a rare congenital malformation resulting from abnormal development of the bronchial tree, resembling type 1 CCAM in the CT image. In one case the solid cystic lesion detected in the CT image was in fact associated with pulmonary sequestration.

\section{Disclosure}

\section{Authors report no conflict of interest.}

\section{References}

1. Chikkannaiah P, Kangle R, Hawal M. Congenital cystic adenomatoid malformation of lung: Report of two cases with review of literature. Lung India 2013; 30: 215-218.

2. Laberge JM, Flageole H, Pugash D, Khalife S, Blair G, Filiatrault D, Russo P, Lees $\mathrm{G}$, Wilson RD. Outcome of the prenatally diagnosed congenital cystic adenomatoid lung malformation: a Canadian experience. Fetal Diagn Ther 2001; 16: 178-186.

3. Laberge JM, Puligandla P, Flageole H. Asymptomatic congenital lung malformations. Semin Pediatr Surg 2005; 14: 16-33.

4. Duncombe GJ, Dickinson JE, Kikiros CS. Prenatal diagnosis and management of congenital cystic adenomatoid malformation of the lung. Am J Obstet Gynecol 2002; 187: 950-954.

5. Shanmugam G, MacArthur K, Pollock JC. Congenital lung malformations - antenatal and postnatal evaluation and management. Eur J Cardiothorac Surg 2005; $27: 45-52$
6. Pramod Puligandla JM, Flageole H. Asymptomatic congenital lung malformations. Semin Pediatr Surg 2005; 14: 16-33.

7. Stocker JT. Congenital pulmonary airway malformation - a new name for and an expanded classification of congenital cystic adenomatoid malformation of the lung. Histopathology 2002; 41: 424-431.

8. Cavoretto P, Molina F, Poggi S, Devenport M, Nikolaides KH. Prenatal diagnosis and outcome of echogenic fetal lung lesions. Ultrasound Obstet Gynecol 2008; 32: 769-783.

9. Sfakianaki A, Copel JA. Congenital cystic lesions of the lung: congenital cystic adenomatoid malformation and bronchopulmonary sequestration. Rev Obstet Gynecol 2012; 5: 85-93.

10. Wilson RD, Hedrick HL, Liechty KW, Flake AW, Johnson AW, Bebbington M, Adzick NS. Cystic adenomatoid malformation of the lung: review of genetics, prenatal diagnosis, and in utero treatment. Am J Med Genet Suppl 2006; 140A: 151-155.

11. Tulandi T, Martin J, Al-Fadhli R, Kabli N, Forman R, Hitkari J, Librach C, Greenblatt E. Congenital malformations among 911 newborns conceived after infertility treatment with letrozole or clomiphene citrate. Fertil Steril 2006; 85: 1761-1765.

12. Riedlinger WFJ, Vargas SO, Jennings RW. Bronchial atresia is common to extralobar sequestration, intralobar sequestration, congenital cystic adenomatoid malformation, and lobar emphysema. Pediatr Dev Pathol 2006; 9: 361-373.

13. Wong A, Vieten D, Singh S, Harvey JG, Holland AJA. Long-term outcome of asymptomatic patients with congenital cystic adenomatoid malformation. Pediatr Surg Int 2009; 25: 479-485.

14. Kunisaki SM, Barnewolt CE, Estroff JA, Ward VL, Nemes LP, Fauza DO, Jennings RW. Large fetal congenital cystic adenomatoid malformations: growth trends and patient survival. J Pediatr Surg 2007; 42: 404-410.

15. Calvert JK, Boyd PA, Chamberlain PC, Said S, Lakhoo K. Outcome of antenatally suspected congenital cystic adenomatoid malformation of the lung: 10 years' experience 1991-2001. Arch Dis Child Fetal Neonatal Ed 2006; 91: F26-F28.

16. Ierullo AM, Ganapathy R, Crowley S, Craxford L, Bhide A, Thilaganathan B. Neonatal outcome of antenatally diagnosed congenital cystic adenomatoid malformations.. Ultrasound Obstet Gynecol 2005; 26; 150-153.

17. Sfakianaki A, Copel JA. Congenital cystic lesions of the lung: congenital cystic adenomatoid malformation and bronchopulmonary sequestration. Rev Obstet Gynecol 2012; 5: 85-93.

18. Kunisaki SM, Barnewolt CE, Estroff JA, Ward VL, Nemes LP, Fauza DO, Jennings RW. Large fetal congenital cystic adenomatoid malformations: growth trends and patient survival. J Pediatr Surg 2007; 42: 404-410.

19. Laberge JM, Puligandla P, Flageole H. Asymptomatic congenital lung malformations. Semin Pediatr Surg 2005; 14: 16-33.

20. McLean SE, Pfeifer JD, Siegel MJ, Jensen ER, Schuler PM, Hirsch R, Mychaliska GB. Congenital cystic adenomatoid malformation connected to an extralobar pulmonary sequestration in the contralateral chest: common origin? J Pediatr Surg 2004; 39: e13-e17.

21. Stanton M, Njere I, Ade-Ajayi N, Patel S, Davenport M. Systematic review and meta-analysis of the postnatal management of congenital cystic lung lesions. J Pediatr Surg 2009; 44: 1027-1033.

22. Kim YT, Kim JS, Park JD, Kang CH, Sung SW, Kim JH. Treatment of congenital cystic adenomatoid malformation - does resection in the early postnatal period increase surgical risk? Eur J Cardiothorac Surg 2005; 27: 658-661.

23. Kim HK, Choi YS, Kim K, Shim YM, Ku GW, Ahn KM, Lee SI, Kim J. Treatment of congenital cystic adenomatoid malformation: should lobectomy always be performed? Ann Thorac Surg 2008; 86: 249-253.

24. Jhun BW, Kim SJ, Kim K, Kim S, Lee JE. The clinical courses of patients with congenital cystic adenomatoid malformation complicated by pneumonia. Yonsei Med J 2015; 56: 968-975.

25. Zeidan S, Gorincour G, Potier A, Ughetto F, Dubus JC, Chrestian MA, Gros se C, Gamerre M, Guys JM, de Lagausie P. Congenital lung malformation: evaluation of prenatal and postnatal radiological findings. Respirology 2009; 14: 1005-1011. 